\title{
Preeklamptik ve Eklamptik Hastalarda Yoğun Bakımda Kalma Süresine Etki Eden Faktörler
}

\author{
Factors Affecting Duration of Intensive Care in Preeclamptic And Eclamptic \\ Patients \\ Engin ÖZTÜRK ${ }^{1}{ }^{(D)}$, Neşe Gül HiLALİ 2
}

1 Şanlıurfa Eğitim Araştırma Hastanesi Kadın Hastalıkları ve Doğum Kliniği, Şanlıurfa, Türkiye 2 Harran Üniversitesi Tıp Fakültesi, Kadın Hastalıkları ve Doğum Anabilim Dalı, Şanlıurfa, Türkiye

Öz.

Amaç: Çalışmamızın amacı kliniğimizde preeklampsi ve eklampsi nedeni ile yoğun bakımda tedavi gören hastalarından yoğun bakımda kalma süresine etki eden faktörlerin araştırımasıdır.

Materyal ve Metod: Harran Üniversitesi Tıp Fakültesi Kadın Hastalıkları ve Doğum Kliniğinde Ocak 2015 ve Ekim 2016 tarihleri arasında preeklampsi ve eklampsi nedeni ile yoğun bakımda tedavi gören 77 hasta retrospektif olarak değerlendirildi. İstatistiksel çalışmalar için SPSS 20.0 paket programı kullanıldı. P değeri < 0.05 altında olanlar istatistiksel olarak anlamlı kabul edildi.

Bulgular: Yoğun bakımda kalma süresini etkileyen faktörler değerlendirildiğinde hastaların yaşı, gebelik sayısı veya doğum şekli ile yoğun bakım servisinde kalma süresi arasında korelasyon izlenmemiş ancak tedavi süresi ile AST ( $r=0.255, p=0.025), A L T(r=0.281, p=0.013)$, idrarda proteinüri $(r=0.263, p=0.021)$ ve LDH $(r=0.267, p=0.019)$ düzeyleri açısından pozitif anlamlı bir ilişki tespit edilmiştir.

Sonuç: Çalışmamızda; preeklampsi ve eklampsi nedeni ile yoğun bakımda takip ettiğimiz hastaların $A L T, A S T, L D H$, gibi laboratuvar parametrelerinin yükselmesi ve proteinüri varlığı, hastaların yoğun bakımda takip sürelerini arttırmıştır.

Anahtar Kelimeler: Preeklampsi, Eklampsi, Yoğun bakım ünitesi

\section{Abstract}

Background: The aim of this study was to investigate the factors affecting the length of stay in the intensive care unit of patients treated in the intensive care unit for preeclampsia and eclampsia. Materials and Methods: Between January 2015 and October 2016, 77 patients who were treated in the intensive care unit for preeclampsia and eclampsia in Harran University, Medical Faculty, Department of Obstetrics and Gynecology were retrospectively evaluated. SPSS 20.0 packet programme was used for statistical studies. P values $<0.05$ were considered statistically significant. Results: When the factors affecting the length of stay in the intensive care unit were evaluated, there was no correlation between age, number of gestations or delivery type and length of stay in the ICU, but the duration of treatment was positively correlated with the factors such as AST $(r=0.255, p=$ $0.025)$, ALT $(r=0.281, p=0.013)$, urine proteinuria $(r=0.263, p=0.021)$ and LDH $(r=0.267, p=$ $0.019)$ levels.

Conclusions: The increase of laboratory parameters such as ALT, AST, LDH, and proteinuria of the patients who were followed up in the intensive care unit due to preeclampsia and eclampsia increased the follow-up period of the patients in the intensive care unit.

Key words: Preeclampsia, Eclampsia, Intensive care unit

\section{Sorumlu Yazar $I$ \\ Corresponding Author}

\section{Dr. Engin Öztürk}

Şanlıurfa Eğitim Araştırma Hastanesi Kadın Hastalıkları ve Doğum Anabilim Dalı, 63250, Şanlıurfa, Türkiye

e-mail: dr.enginozturk@hotmail.com Tel: +90505-062-52-87

Kısa başlık (running title): Gebelik ve yoğun bakım

Geliş tarihi / Received:

25.11.2019

Kabul tarihi / Accepted: 21.02.2020

\section{DOI: 10.35440/hutfd.650535}

Çalışmamız Türkiye Jinekoloji ve Obstetri Derneğinin 24-28 Nisan 2019'da düzenlemiş olduğu 17. Ulusal Jinekoloji ve Obstetrik Kongresi'nde sözel sunum olarak sunulmuştur.

Bu çalışma Dr. Engin ÖZTÜRK'ün Tıpta Uzmanlık Tezinden üretilmiştir 


\section{Giriş}

Preeklampsi obstetrinin çözüme kavuşmamış önemli problemlerinden biridir ve gelişmiş ülkelerde dahi maternal mortalite sebepleri arasında önemli bir yer kaplamaktadır. Tüm gebeliklerin \%5-10'u hipertansiyon ile komplike olur (1). Preeklampsinin patogenezi karmaşıktır ve patojenik faktörler temel olarak anormal sistemik bir enflamatuar yanıt, plasental iskemi ve hipoksi, artmış oksidatif stres ile anjiojenik ve antianjiojenik dengelerin disregülasyonunu içerir (2). Geliştirilen birçok teori olmasına rağmen etyolojisi tam olarak aydınlatılamadığı için günümüzde etkili primer korunma bilinmemektedir. Korunma bilinmemekle birlikte preeklampsi geliştiği zaman hem maternal hem de neonatal ciddi morbiditeler ve mortalite ile seyredebilen önemli bir obstetrik komplikasyondur (3). Mevcut çalışmamız ile kliniğimizde preeklampsi ve eklampsi nedeni ile yoğun bakımda tedavi gören hastaların, yoğun bakımda kalma süreçlerini geriye dönük tekrar gözden geçirip, yoğun bakımda kalma sürelerine etki eden faktörleri araştırmayı planladık.

\section{Materyal ve Metod}

Çalışmamızda Ocak 2015 ve Ekim 2016 tarihleri arasında Kadın Hastalıkları ve Doğum Kliniğimizde preeklampsi ve eklampsi nedeni ile tedavi gören hastalar arasında yoğun bakımda kalanlarda yoğun bakımda kalma süresine etki eden faktörler araştıııldı. Çalışma için 03-11-2016 tarihinde sayı no 74059997-050.04.04 olan 10 no'lu oturum ve 10 sayılı kararı ile Harran Üniversitesi Tıp Fakültesi Etik Kurulu'ndan onay alındı. İlgili tarihte Kadın Hastalıkları ve Doğum Kliniği adına yoğun bakım ünitesinde yatışlı görünen hastaların elektronik veri tabanındaki bilgileri tarandı. Preeklampsi ve eklampsi tanısı ile takip edilen, arşiv dosya verileri uygun olan 77 hasta çalışmaya dahil edildi. Hasta dosyalarından preeklampsi ve eklampsi hastalarının klinik başvuru anındaki şikâyetleri, klinik muayene bulguları, ultrasonografi bulguları kaydedildi. Kliniğimizde preeklampsi tanısı literatüre uygun olarak, daha önceden normotansif olduğu bilinen gebeliğinin ikinci yarısından itibaren sistolik tansiyonu $140 \mathrm{mmHg}$ ve diyastolik tansiyonu $90 \mathrm{mmHg}$ veya üzerinde olan hastalarda ek olarak aşağıdaki durumlardan bir veya birkaçının bir arada bulunması ile konulmaktadır (4);

1) Proteinüri( $300 \mathrm{mg} / 24$ saatlik idrar, veya spot idrarda protein/kreatinin $\geq 03$ spot idrarda protein $>1+$ veya spot idrarda protein $>30 \mathrm{mg} / \mathrm{dl}$ )

2) Trombositopeni $(<100.000 / \mu \mathrm{L})$

3) Karaciğer enzimlerinde yükselme ( laboratuar eşik referans değerinin en az iki katı)

4) Pulmoner ödem

5) Santral sinir sistemi ile ilgili bulgular.

Eklampsi tanısı ise daha önceden nörolojik problemi olmayan hastanın preeklampsi tanısının ardından tonik klonik nöbet geçirmesi durumunda konulmaktadır. Kliniğimizde eklamptik ve de preeklamptik hastalar takip edilirken özellikle tansiyon değerleri sistolik $160 \mathrm{mmHg}$ ve/veya diyastolik tansiyon $110 \mathrm{mmHg}$ değerini bulur veya aşarsa, bulunan değer dakikalar içerisinde konfirme edilmekte, hastalar yoğun bakım ünitesine alınarak antihipertansif tedavi uygulanmaktadır. Bunun yanısıra ek organ disfonksiyonu olan hastalar klinik durumlarının şiddetine göre de yoğun bakımda takip edilmektedirler. Retrospektif olarak değerlendirilen hastaların demografik özellikleri (yaş, gravida, geçirilmiş cerrahi sayısı, gebelik haftası ), hasta epikrizinde klinik başvuru anındaki laboratuar bulguları (hemoglobin, AST, ALT, LDH, GGT, trombosit değerleri ), hastalardan alınan anamnez ve klinik ve sonografik muayeneye göre ek hastalık olup olmadığı (dekolman plesanta, gestasyonel diyabetus mellitus vs), hastalara yoğun bakımda iken uygulanan tedavi ve tedavi süresi retrospektif olarak kaydedildi.

\section{İstatistiksel analiz}

İstatistiksel çalışmalar için SPSS 20.0 Paket Programı kullanıldı. Sayısal veriler ortalama \pm standart deviasyon olarak sunuldu. Yoğun bakımda kalma süresi ve etkileyen faktörler arasındaki iliş̧i Pearson Korelasyon Analizi ile değerlendirildi. $P$ değeri $<0.05$ altında olanlar istatistiksel olarak anlamlı kabul edildi.

\section{Bulgular}

Çalışmaya dâhil edilen hastaların demografik ve laboratuvar verileri Tablo 1'de sunulmuştur.

Tablo 1. Çalışmaya Dahil Edilen Hastaların Demografik Verileri ile Laboratuvar Sonuçları

\begin{tabular}{lll} 
& $\begin{array}{l}\text { Ortalama } \pm \text { Standart Devi- } \\
\text { asyon }\end{array}$ & Min-Max \\
\hline Yaş(yıl) & $29,48 \pm 7,29$ & $15-43$ \\
Gravida & $3,71 \pm 2,92$ & $1-15$ \\
Gebelik Haftası & $32,75 \pm 4,74$ & $20-40$ \\
Geçirilmiş Sezaryen Sayısı & $1,84 \pm 0,72$ & $0-5$ \\
Yoğun Bakım YatıŞ Sü- & $3,08 \pm 1,70$ & $1-10$ \\
resi(gün) & & \\
Hemoglobin(gr/dl) & $11,64 \pm 2,13$ & $6,88-$ \\
& & 16,70 \\
Platelet(mm3) & $19-561$ & $19-561$ \\
AST(U/L) & $85,01 \pm 132,43$ & $9-785$ \\
ALT(U/L) & $68,18 \pm 108,52$ & $6-564$ \\
Proteinüri(g/dl) & $2,42 \pm 1,01$ & $0-4$ \\
LDH(mg/dl) & $480,66 \pm 304,24$ & $122-1533$ \\
\hline AST:Aspartat aminotransferaz ALT:Alanin aminotransferaz LDH: & Laktat dehid
\end{tabular}

AST: Aspartat aminotransferaz ALT: Alanin aminotransferaz LDH: Laktat dehidrogenaz

Çalışmaya dahil edilen 77 hastanın yaş ortalaması $29.48 \pm 7.29 \mathrm{yll}$, gebelik sayısı ortalaması $3.71 \pm 2.92$, gebelik haftası ise $32.75 \pm 4.74$ idi. Çalışmaya dahil edilen 77 hastanın 32(\%41.6) 'nın daha önce geçirilmiş sezaryen öyküsü mevcut iken 45 hastamızın geçirilmiş sezaryen öyküsü yoktu. Hastalarımızın öyküleri değerlendirildiğinde; 77 hastanın 4 (\%5.2)'inde gestasyonel diabetes mellitus, 11 hastada (\%14.3) plasenta dekolmanı mevcuttur. 48 
(\%62.3) hastada ek hastalık yoktu. Değerlendirilen hastaların yoğun bakımda kalma süreleri $3.09 \pm 1.7$ gün olarak tespit edilmiştir. Yoğun bakımda kalma süresini etkileyen faktörler değerlendirildiğinde hastaların yaşı, gebelik sayısı veya doğum şekli ile arada korelasyon izlenmemiş ancak tedavi süresi ile AST $(r=0.255, p=0.025)$, ALT ( $r=0.281$, $p=0.013)$, idrarda proteinüri $(r=0.263, p=0.021)$ ve $L D H$ $(r=0.267, p=0.019)$ düzeyleri açısından pozitif anlamlı bir ilişki tespit edilmiştir.

\section{Tartışma}

Hastaların yoğun bakımda kalma sürelerini etkileyen faktörler değerlendirildiğinde hastaların yaşı, gebelik sayısı veya doğum şekli ile arada korelasyon izlenmemiş ancak tedavi süresi ile AST, ALT, idrarda proteinüri ve LDH düzeyleri arasında pozitif anlamlı bir ilişki tespit edilmiştir. Hastalarımızda yaş faktörünün yoğun bakımda kalma süresi üzerine anlamlı bir etki etmediğini bulduk, bu anlamda çalışmamız literatürle uyumlu idi $(5,6,7)$. Ayrıca daha önceden yapılmış olan çalışmalar incelendiğinde, gebelik sayısı ve gebelik haftasının preeklamptik ve eklamptik hastaların yoğun bakımda kalma süreleri üzerinde etkili olmadığı gözlenmektedir (8-10). Biz de çalışmamızda gebelik sayısı ve haftası ile arada istatistiksel olarak anlamlı bir ilişki izlemedik. İşler ve arkadaşları çalışmalarında preeklamptik ve eklamptik hastalarda ALT, AST ve LDH gibi laboratuar parametrelerindeki yüksekliğin hastalığın şiddeti ile uyumlu olduğunu göstermişlerdir (11). Biz de çalışmamızda aynı laboratuar parametrelerini, hastalığın şiddeti ile uyumlu olarak yüksek bulduk ve yoğun bakımda kalma süresini uzattığını gözlemledik.

Hipertansif hastalıklar, tromboembolik hadiseler ve obstetrik kanama dünya genelindeki en önemli üç maternal mortalite nedenleridir. Hipertansiyona bağlı maternal mortalite gelişmiş ülkelerde dahi önlenememektedir ve preeklamptik hastaları öngörmek için ideal bir labaratuvar parametresi bulunmamaktadır. Genellikle de hastalar, hastalık ile ilgili tablo oturduktan sonra refere edilmektedir. Hastaların yönetimi esnasında, laboratuar ve klinik parametrelerin detaylı değerlendirilmesi gelecekteki hastaları daha erken dönemde tespit ve fayda açısından yarar sağlayabilir. Bu alanda yapılacak çalışmalar hastalığın öngörüsüne katkıda bulunabilir.

Çalışmamızda preeklamptik ve eklamptik hastaların yoğun bakımda kalma süreleri üzerine etki eden faktörleri irdeleyip gelecekteki hastalar için yararlı olabilmeyi umut ettik. Preeklamptik ve eklamptik hastaların yoğun bakımda kalma süreleri hastaların tansiyon değerlerinin şiddetine ve bazı laboratuvar parametrelerinin yükselmesine bağlı olarak uzayabilmektedir. Hastalığın şiddeti arttıkça yoğun bakımda kalma süresi uzamaktadır. Çalışmamızın retrospektif olması ve az sayıda hasta ile yapıımış olması önemli kısıtılıklarıdır, ve de mevcut çalışmamız ile, literatüre benzer sonuçlar gözlemledik. Bu alanda daha fazla sayıda hasta ile daha kapsamlı yapılacak çalışmalara intiyaç bulunmaktadır.

Etik Onam: Çalışma için 03-11-2016 tarihinde sayı no 74059997-050.04.04 olan 10 no'lu oturum ve 10 sayilı kararı ile Harran Üniversitesi Tıp Fakültesi Etik Kurulu'ndan onay alındı.

\section{Kaynaklar}

1. Hebisch G. Hypertension and pregnancy Schweiz Rundsch Med Prax 2003; 92(50): 2137-43.

2. Phipps E, Prasanna D, Brima W, Jim B. Preeclampsia: Updates in Pathogenesis, Definitions, and Guidelines. Clin J Am Soc Nephrol. 2016;11(6):1102-1113.

3. Jim B, Karumanchi SA: Preeclampsia: Pathogenesis, prevention, and long-term complications. Semin Nephrol, 2017; 37(4): 386-97

4. American College of Obstetricians and Gynecologists. Hypertension in pregnancy. Developed by the Task Force on Hypertension in Pregnancy. 2013.

5. Dekker GA, de Vries JI, Dozlitzsch PM, Huijgens PC, von Blomberg $\mathrm{BM}$, Jakobs $\mathrm{C}$, et al. Underlying disorders associated with severe earlyonset preeclampsia. Am J Obstet Gynecol. 1995 oct;173 (4): 1042-8.

6. August P: Hypertensive disorders of pregnancy. In .Burrow GN, Duffy $T$ (eds). Medical complications during pregnancy. Fifth edition WB Saunders Company, 1999: 53-79

7. Kireççi A: Ağır Preeklampsi ve Trombofili Illişkisi. Uzmanlık Tezi, İstanbul: Göztepe Eğitim Araştırma Hastanesi Kadın Hastalıkları ve Doğum Kliniği, 2005

8. D'Anna R, Baviera G, Corrado F, Leonardi I, Buemi M, Jasonni VM. Is mid-trimester maternal serum inhibin-A a marker of preeclampsia or intrauterine growth restriction? Acta Obstet Gynecol Scand 2002 Jun; 81(6): 540-3.

9. Schwarze A, Nelles I, Krapp M, Friedrich M, Schmidt W, Diedrich K, Axt Doppler ultrasound of the uterine artery in the prediction of severe complications during low-risk pregnancies Arch Gynecol Obstet 2005 Jan; 271(1): 46- 52

10. Axt-Fliedner R. Second trimester uterine artery Doppler ultrasound as a screening test for adverse pregnancy outcome Clin Exp Obstet Gynecol 2004; 31(1): 9-11.

11. Isler CM, Rinehart BK, Terrone DA, Martin RW, Magann EF, Martin JN Jr. Maternal mortality associated with HELLP (hemolysis, elevated liver enzymes, and low platelets) syndrome. Am J Obstet Gynecol 1999; 181:924-28. 